\title{
Pengaruh Antara Motivasi Kerja Guru IPA dan Displin Terhadap Prestasi Kerja
}

\author{
Darmawan Harefa \\ STKIP Nias Selatan \\ e-mail: darmawan90_h24@yahoo.co.id
}

Received: 28 Juli 2020; Revised: 20 Agustus 2020; Accepted: 28 Agustus 2020

DOI: http://dx.doi.org/10.37905/aksara.6.2.97-102.2020

\begin{abstract}
Abstrak
Tujuan penelitian ini adalah untuk mengetahui seberapa besar pengaruh motivasi kerja Guru IPA dan disiplin dengan prestasi kerja guru di SMP Nimarwati Lagundri. Metode penelitian yang digunakan dalam penelitian ini adalah metode survey dengan analisis korelasional. Sedangkan data dan informasi di lapangan dijaring dengan bantuan kuesioner. Penelitian ini berdasarkan pada koefisien determinasi diperoleh sebesar 0,595 sedangkan $t_{\text {hitung }}$ sebesar 6,959 . Variabel bebas motivasi kerja $\left(\mathrm{X}_{1}\right)$ dan disiplin $\left(\mathrm{X}_{2}\right)$ baik secara masing-masing maupun bersama-sama memberikan kontribusi yang signifikan terhadap variabel terikat prestasi kerja (Y). kontribusi masing-masing variabel bebas terhadap variabel terikat ada : a) Variabel disiplin sebesar 59,5\%. b) Variabel motivasi kerja guru IPA sebesar 50,3\%, Kontribusi kedua variabel bebas secara bersama-sama terhadap variabel terikat adalah 69,2\%. Dengan diketahuinya sumbangan variabel motivasi kerja $\left(X_{1}\right)$ dan disiplin $\left(X_{2}\right)$ sebesar $69,2 \%$ terhadap prestasi kerja guru, maka dapat diambil kesimpulan bahwa 30,8\% prestasi kerja guru disebabkan oleh faktor-faktor lain.
\end{abstract}

\section{Kata Kunci}

Pengaruh; Displin; Motivasi, Guru IPA, Prestasi

\section{Pendahuluan}

Salah satu masalah yang dihadapi dunia pendidikan kita adalah masalah lemahnya proses pembelajaran. Menurut (Sanjaya 2009) Guru dalam implementasi SPP mempunyai peran yang sangat penting. Hal ini disebabkan keberhasilan implementasi standar proses pendidikan itu sangat ditentukan oleh kemampuan guru, sebab guru merupakan orang pertama yang berhubungan dengan pelakssanaan program pendidikan (Sanjaya 2009). Organisasi baik formal maupun non formal melakukan peranan dominan manusia sebagai motor penggerak jalannya organisasi untuk mencapai tujuan yang sebelumnya telah ditetapkan. Organisasi adalah setiap bentuk persekutuan antara dua orang atau lebih yang bekerja sama untuk mencapai suatu tujuan bersama dan terikat secara formal dalam suatu ikatan hirarkhi dimana selalu terdapat hubungan antara seseorang dan sekelompok orang atau di sebut pimpinan dan bawahan. Sukses atau tidaknya suatu organisasi sesuai dengan tujuan yang di harapkan sangat di tentukan oleh manusia-manusia sebagai tenaga penggerak yang berkualitas.

Sekolah merupakan suatu organisasi yang di dalamnya terdapat guru dan tenaga kependidikan lainya di mana yang bersangkutan mempunyai tugas dan merupakan ujung tombak dalam mencapai keberhasilan pendidikan. Guru sebagai 


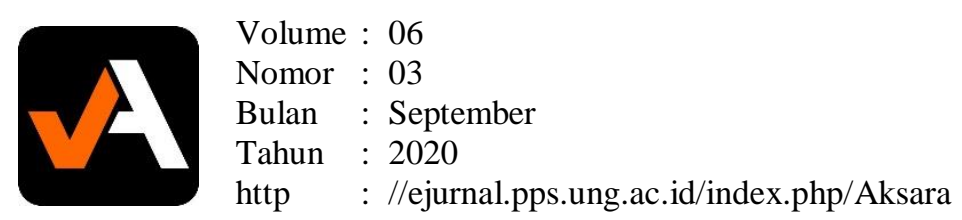

tenaga professional dituntut menjadi manusia yang berdedikasi tinggi, loyal, berkemauan keras, memiliki etos kerja yang tinggi, bermotivasi tinggi dan berdisiplin yang dapat mendukung berhasilnya visi dan misi suatu sekolah sebagai organisasi.

Untuk menjamin terpeliharanya tata tertib dan kelancaran pelaksanaan tugas dalam mencapai tujuan sekolah, maka diperlukan guru yang penuh kesetiaan dan ketaatan pada peraturan yang berlaku dan sadar akan tanggung jawabnya untuk menyelenggarakan tujuan sekolah. Dengan kata lain kedisiplinan para guru sangat diperlukan dalam meningkatkan tujuan sekolah. Menurut pendapat (Bejo 2005) memandang bahwa disiplin ialah suatu sikap menghormati, menghargai, patuh, dan taat terhadap peraturan-peraturan yang berlaku, baik yang tertulis maupun tidak tertulis serta sanggup menjalankannya dan tidak mengelak untuk menerima sanksi-sanksinya apabila ia melanggar tugas dan wewenang yang diberikan kepadanya. Sejalan dengan (Atmodiwirjo 2000) mengemukakan bahwa disiplin ialah setiap usaha mengkoordinasikan perilaku seseorang pada masa yang akan datang dengan mempergunakan hukum dan ganjaran. Definisi diatas memfokuskan pengertian disiplin sebagai usaha untuk menata perilaku seseorang agar terbiasa melaksanakan sesuatu sebagaimana mestinya yang dirangsang dengan hukuman dan ganjaran.

Faktor-faktor yang berpengaruh terhadap disiplin kerja, yaitu (1) Pemberian gaji, (2) Pemberian kesempatan dan dorongan untuk mengembangkan karier, (3) Pemberian istirahat yang memadai, (4) Pemberian penghargaan atas jasa atau kesetiaan terhadap organisasi, baik Berupa material maupun inmaterial, (5) Pemberian kesempatan berhimpun dalam organisasi pegawai, (6) Pemberian fisilitas kerja maunpun social yang adil, (7) Keselamatan, keamanan dan kesehatan kerja, (8) Pemberian perangsang, (9) Pemberian atau pengaturan rekreasi, dan (10) Pemberian hari tua atau pension (A.S. Moenir 2010). Untuk menerapkan disiplin kerja perlu adanya kesadaran, keteladanan dan ketaatan. Pengaturan kesadaran merupakan faktor utama, sedangkan keteladanan dan ketaatan merupakan faktor pelindung. Ikatan moral untuk menegakkan disiplin tidaklah cukup membuat pegawai dapat bekerja dengan kemauan yang tinggi, oleh karena itu perlu dilengkapi usaha-usaha secara moralitas formal, yaitu berupa sanksi dan hukuman bagi pelanggar aturan dan tata tertib. Demikian pula aturan-aturan yang dibuat hendaknya tidak dipandang sebagai ancaman melainkan dapat mendorong untuk bekerja lebih bertanggung jawab. (Fathoni. 2006) Kedisiplinan dapat diartikan bila mana pegawai selalu datang dan pulang pada tepat waktu yang ditentukan oleh kepala menajer, pimpinan dari masing-masing instansi.

Banyak sekali pendapat tentang motif diartikan sebagai daya upaya yang mendorong seseorang untuk melakukan sesuatu. Motivasi adalah perubahan energy dalam diri seseorang yang ditandai dengan munculnya "feeling" dan didahului dengn tanggapan terhadap adanya tujuan (Sardiman 2011). Sejalan dengan pendapat (Sanjaya 2009) "motivasi sangat erat hubungannya dengan kebutuhan, sebab memang motivasi muncul karena kebutuhan, seseorang akan terdorong untuk bertindak manakala dalam dirinya ada kebutuhan”. Motivasi guru IPA merupakan salah satu pembelajaran yang didapatkan dari alam sekitarnya. Motivasi dapat juga dikatakan sebagai sebagai rangkaian usaha untuk meyediakan kondisi-kondisi tertentu, sehingga seseorang mau dan ingin melakukan sesuatu, dan bila ia tidak suka, maka maka akan berusaha untuk meniadakan atau mengelakan perasaan tidak suka itu. Menurut pendapat (Trianto 2009) memotivasi guru IPA suatu yang menari dengan cara belajar yang sistematis dilakukan secara 
umum terbatas pada gejala-gejala alam, lahir dan berkembang pembelajaran melalui metode ilmiah seperti observasi dan eksperimen.

Prestasi kerja pegawai adalah tingkat hasil rata-rata yang dicapai oleh pegawai yang bersangkutan dalam satu hari masa kerja maupun dalam kontinuitas pelaksanaan pekerjaan (Anoraga 2012). Untuk meyakinkan bahwa guru IPA sebagai pekerja profesional, marilah kita tinjau syarat-syarat atau ciri pokok dari pekerjaan profesioal mnenurut (Sanjaya 2009) a) pekerjaan professional ditunjang oleh suatu ilu tertentu secara mendalam yang hnya mungkin diperoleh dari lembaga-lembaga pendidikan yang sesuai, sehingga kinerjanya didaasarkan kepada keilmuan yang dimilikinya yang dapat dipertanggungjawabkan secara ilmiah, b) suatu profesi menekankan kepada suatu keahlian dalam bidang tertentu yang spesifik sesuia dengan jenis profesinya, sehingga antara profesi yang satu dengan yang lainnya dapat dipisahkan secara tegas, c) tingkat kemampuan dan keahlian suatu profesi didasarkan kepada latar belakang pendidikan yang dialaminya yang diakui oleh masyarakat, sehingga semakin tinggi latar belakang pendidikan akademik sesuai dengan profesinya, semakin, semakin tinggi pula tingkat keahliannya, dengan demikian semakin tinggi pula tingkat penghargaan yang diterimanya, d) suatu profesi selain dibutuhkan oleh masyarakat juga memiliki dampak terhadap social kemasyarakatan, sehingga masyarakat memiliki kepekaan yang sangat tinggi terhadap setiap efek yang ditimbulkannya dari pekerjaan profesinya itu.

Menurut (Djoko Prakoso dan I ketut Murtika 2004) kegunaan peningkatan prestasi kerja untuk : a) perencanaan dan pengembangan karir., b) perbaikan dan perestasi kerja, c) penyesuaian-penyesuaian konsasi, d) keputusan-keputusan penempatan, e) kebutuhan-kebutuhan latihan dan pengembanganan, f) Penyimpanganpenyimpangan proses staffing, g) Kesempatan kerja yang adil, h) tantangan-tantangan eksternal. Seorang pegawai pemerintah atau swasta yang mempunyai prestasi akan memperoleh penghargaan, perhatian dari atasannya serta memperoleh penilaian positif dari rekan-rekan kerjanya. Bentuk penghargaan atau perhatian dari atasnya bisa berupa kenaikan gaji, kenaikan pangkat, hadiah, fasilitas dan lainya. Prestasi kerja tidak dimiliki oleh semua pegawai, melainkan mereka yang mempmunyai sifat rajin, ulet, semangat, penuh gairah, motifasi yang kuat dan disiplin yang tinggi.

Untuk memperoleh prestasi kerja tidaklah mudah bagi setiap orang, melainkan harus memiliki syarat. Menurut (Djoko Prakoso dan I ketut Murtika 2004) syarat tersebut adalah sebagai berikut : a) empunyai kecakapan dan menguasai segala bidang tugasnya dan bidang lain yang berhubungan dengan tugasnya. 2) mempunyai ketrampilan yang sangat baik, 3) mempunyai pengalaman yang sangat luas dibidang tugasnya dan bidang lain yang berhubungan dengan tugasnya. 4) elalu bersungguhsungguh dan tidak mengenal waktu dalam melaksanakan tugasnya, 5) mempunyai kesegaran dan kesehatan jasmani dan rohani yang baik, 6) selalu melaksanakan tugas secara berdaya guna dan berhasil guna, 8) hasil kerjanya jauh melebihi hasil kerja ratarata yang ditentukan, baik dalam arti mutu maupun dalam arti jumlah.

Insentif berperan dalam mendorong orang berprestasi dalam bekerja. Tetapi peran itu harus di lihat dalam konteks cakupan faktor-faktor motivasi secaraa keseluruhan. Setiap sekolah harusmampuh mengembangkan sistem pengupahan yang dapat memotivasi guru. Semakin kecil penghasilan seseorang jumlah gajih merekaa semakin penting, semakin tinggi penghasilan seseorang semakin dalam ia 


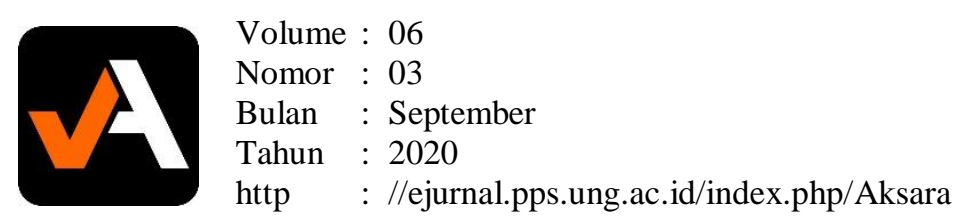

mengidentikkan diri dengan apa ia kerjakan, uang menjadi relative kurang penting. Setiap orang menginginkan uang, dan uang selalu menjadi topik pembicaraan utama dan di tempat mereka bekerja yang menghendaki gajih cukup sesuai harapan dan kebutuhan sehari-haribisa terpenuhi. Gajih menjadi penting karena beberapa hal, yaitu (1) Gajih menjamin sesuatu mata pencaharian karena itu merupakan dorongan untuk bekerja, (2) Besar gajih menunjukan status pekerja, tidak hanya dalam dalam hirarki perusahaan internal, tetapi juga dalam hubungannya dengan tetangga, kawan, dan kelompok lainnya dalam masyarakat, dan (3) Suatu kenaikan gajih adalah penegasan keberhasilan anda dalam bekerja (Hagemann 2015).

Pemberian intensif yang tinggi kepada pegawai di perusahaan atau guru di sekolahan penting karena dapat meningkatkan gairah dan semangat kerja, namu demikian hal ini tidak menjadi faktor penentu untuk mencapai prestasi kerja seseorang. Hal-hal yang mendorong orang berusaha lebih giat bekerja adalah kesejahteraan pribadi, hubungan yang baik di antara kawan sekerja.

Dalam proses pembelajaran, motivasi merupakan salah satu aspek dinamis yang sangat penting. Motivasi berfungsi sebagai pendorong atau perangsang bagi para siswa untuk melakukan aktivitas belajarnya. Menurut pendapat (Sardiman 2011) Sehubungan dengan hal tersebut ada tiga fungsi motivasi antara lain :a) Mendorong manusia untuk berbuat, sebagai penggerak atau motor yang melepaskan energy, b) Menentukan arah perbuatan, yakni ke arah tujuan yang hendak dicapai. c) Menyeleksi perbuatan, yakni menentukan perbuatan-perbuatan apa yang harus dikerjakan yang serasi guna mendapati tujuan, dengan menyisihkan perbuatan-perbuatan yang tidak bermanfaat bagi tujuan tersebut

Untuk itu idealnya, kegiatan pendidikan harus dilakukan terus-menerus tanpa batas waktu dan usia. Oleh karena itu pendidikan dapat diselenggarakan oleh sekolah atau luar sekolah. Pendidikan yang diselenggarakan oleh sekolah disebut pendidikan normal dan pendidikan diselenggarakan diluar sekolah disebut pendidikan non formal. Pendidikan formal pada umumnya hanya terpola pada kerangka-kerangka teori (kognitif). Adapun implikasi dari kerangka teori dilanjutkan melalui proses pelatihan untuk memperoleh keterampilan (skill).

Produktivitas pegawai disamping ditentukan oleh faktor pelatihan juga dipengaruhi oleh faktor motivasi dari pegawai yang bersangkutan. Motivasi kerja pegawai adalah suatu dorongan yang ada dalam diri individu untuk melakukan kegiatan. Motivasi kerja dipengaruhi oleh faktor dari dalam maupun dari luar individu. Jika motivasi kerja individu tinggi, maka produkvitas individu juga tinggi atau sebaliknya jika motivasi kerja individu rendah, maka produkvitas individu juga rendah. Dengan demikian maka motivasi kerja-motivasi kerja merupakan faktor yang juga sangat mempengaruhi produkvitas pegawai. Oleh sebab itu instansi harus mampu mendorong motivasi kerja yang dimiliki oleh pegawai.

\section{METODE}

Metode penelitian yang digunakan dalam penelitian ini adalah motode survei dengan analisis korelasional. Artinya data dijaring dengan bantuan kuesioner. Variabel yang diteliti sebanyak tiga variabel yaitu motivasi kerja $\left(\mathrm{X}_{1}\right)$ dan disiplin kerja $\left(\mathrm{X}_{2}\right)$ merupakan variabel bebas dan prestasi kerja guru (Y) merupakan variabel terikat (Supardi 2012). Desain gambar konstelasi penelitian variabel yang diteliti digambarkan sebagai berikut : 


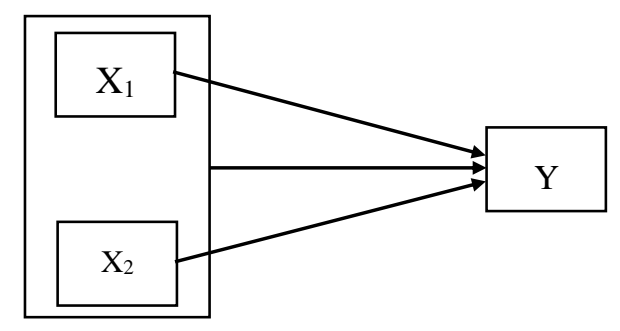

Keterangan :

\section{Gambar.1. Konstelasi Variabel Penelitian}

$\mathrm{X}_{1}=$ Motivasi Kerja

$\mathrm{X}_{2}=$ Disiplin Kerja

$\mathrm{Y}=$ Prestasi Kerja Guru

Instrumen penelitian untuk variabel bebas dan variabel terikat dikembangkan dalam bentuk kuesioner model skala Likert yang bertujuan untuk mengukur motivasi kerja, disiplin kerja dan prestasi kerja guru. Pengembangan kuesioner dengan pertimbangan : (a) penentuan indikator dan kisi-kisi variabel, (b) pembuatan kumpulan pernyataan beserta taraf skala, (c) dikonsultasikan kepada dosen pembimbing, kemudian (d) diujicobakan untuk menentukan validitas dan reliabilitas.

Instrumen penelitian dijabarkan berdasarkan indikator-indikator yang dikemukakan para ahli. Indikator dari variabel yang dijabarkan adalah instrumen motivasi kerja $\left(\mathrm{X}_{1}\right)$, instrumen disiplin kerja $\left(\mathrm{X}_{2}\right)$, dan instrumen prestasi kerja guru $(\mathrm{Y})$. Ketiga instrumen tersebut dirancang sendiri oleh penulis berdasarkan ciri-ciri atau indikator dari ketiga variabel tersebut sebagaimana dikemukakan oleh para ahli.

\section{Hasil dan Pembahasan}

Hasil

Daftar angket penelitian yang penulis sampaikan kepada responden sebanyak 35 orang, kemudian diteliti, diedit, dan dianalisis sesuai dengan pengolahan data. Angket penelitian ini kemudian diberi skor sesuai dengan jawaban responden dan dijumlahkan. Proses penelitian harus dilakukan secara hati-hati agar tidak mengalami kekeliruan dalam merekapitulasi. Hasil rekapitulasi skor untuk masing-masing variabel ini selanjutnya menggunakan alat bantu komputer program SPSS 17.0 for Windows. Rekapitulasi jumlah skor untuk masing-masing variabel dapat dilihat pada table. 1 dibawah ini: 
http : //ejurnal.pps.ung.ac.id/index.php/Aksara

Tabel. 1. Rekapitulasi Jumlah Skor Masing-masing Variabel

\begin{tabular}{cccccccc}
\hline NO & $\mathbf{X}_{\mathbf{1}}$ & $\mathbf{X}_{\mathbf{2}}$ & $\mathbf{Y}$ & $\mathbf{N O}$ & $\mathbf{X}_{\mathbf{1}}$ & $\mathbf{X}_{\mathbf{2}}$ & $\mathbf{Y}$ \\
\hline 1 & 72 & 71 & 73 & 18 & 78 & 77 & 82 \\
2 & 75 & 78 & 75 & 19 & 73 & 74 & 77 \\
3 & 75 & 76 & 72 & 20 & 70 & 71 & 72 \\
4 & 74 & 71 & 72 & 21 & 70 & 71 & 71 \\
5 & 70 & 74 & 72 & 22 & 76 & 80 & 80 \\
6 & 76 & 78 & 78 & 23 & 76 & 80 & 83 \\
7 & 74 & 77 & 76 & 24 & 75 & 80 & 84 \\
8 & 80 & 76 & 77 & 25 & 75 & 76 & 80 \\
9 & 70 & 72 & 74 & 26 & 75 & 76 & 81 \\
10 & 74 & 78 & 75 & 27 & 76 & 80 & 81 \\
11 & 72 & 71 & 72 & 28 & 74 & 75 & 80 \\
12 & 70 & 71 & 71 & 29 & 70 & 72 & 70 \\
13 & 74 & 70 & 71 & 30 & 73 & 74 & 80 \\
14 & 74 & 71 & 71 & 31 & 74 & 78 & 82 \\
15 & 80 & 77 & 84 & 32 & 78 & 75 & 80 \\
16 & 80 & 74 & 82 & 33 & 70 & 71 & 70 \\
17 & 76 & 77 & 83 & 34 & 76 & 77 & 82 \\
18 & 78 & 77 & 82 & 35 & 74 & 73 & 72 \\
\hline
\end{tabular}

Data rekapitulasi jumlah skor untuk masing-masing variabel tersebut diatas diproses melalui bantuan komputer dengan program SPSS 17.0 for windows setelah dilakukan uji standar residual terhadap data yang outlier maka rangkuman data variabel motivasi kerja $\left(\mathrm{X}_{1}\right)$ dapat dilihat sebagaimana pada tabel dibawah ini :

Tabel. 2. Data Statistik Variabel Motivasi Kerja Guru IPA

\begin{tabular}{llcc}
\hline & & Statistic & Std. Error \\
\hline \multirow{4}{*}{$95 \%$ Confidence Interval for Mean } & Mean & 74.26 & .493 \\
& Lower Bound & 73.26 & \\
& Upper Bound & 75.26 & \\
& $5 \%$ Trimmed & 74.17 & \\
Mean & & \\
Median & 74.00 & \\
Variance & 8.491 & \\
& Std. Deviation & 2.914 & \\
Minimum & 70 & \\
$\mathrm{X}_{1}$ & Maximum & 80 & \\
& Range & 10 & \\
& Interquartile & 4 & .398 \\
& Range & & .778 \\
\hline
\end{tabular}


Data rekapitulasi jumlah skor untuk masing-masing variabel tersebut diatas diproses melalui bantuan komputer dengan program SPSS 17.0 for windows setelah dilakukan uji standar residual terhadap data yang outlier maka rangkuman data variabel disiplin $\left(\mathrm{X}_{2}\right)$ dapat dilihat sebagaimana pada table. 3 dibawah ini :

Tabel. 3.Data Statistik Variabel Disiplin

\begin{tabular}{llcc}
\hline & & Statistic & Std. Error \\
\hline \multirow{3}{*}{$95 \%$ Confidence Interval for Mean } & Mean & 74.91 & .534 \\
& Lower Bound & 73.83 & \\
& Upper Bound & 76.00 & \\
& $5 \%$ Trimmed Mean & 74.88 & \\
& Median & 75.00 & \\
& Variance & 9.963 & \\
$\mathrm{X}_{2}$ & Std. Deviation & 3.156 & \\
& Minimum & 70 & \\
& Maximum & 80 & \\
& Range & 10 & .398 \\
& Interquartile Range & 6 & .778 \\
\hline
\end{tabular}

Data rekapitulasi jumlah skor untuk masing-masing variabel tersebut diatas diproses melalui bantuan komputer dengan program SPSS 17.0 for windows setelah dilakukan uji standar residual terhadap data yang outlier maka rangkuman data variabel prestasi kerja guru (Y) dapat dilihat sebagaimana pada tabel 4. dibawah ini :

Tabel.4. Data Statistik Variabel Prestasi Kerja Guru IPA

\begin{tabular}{llcc}
\hline & & Statistic & Std. Error \\
\hline $95 \%$ Confidence Interval for Mean & Mean & 76.71 & .805 \\
& Lower Bound & 75.08 & \\
& Upper Bound & 78.35 & \\
& $5 \% \quad$ Trimmed & 76.68 & \\
Mean & & \\
& Median & 77.00 & \\
Variance & 22.681 & \\
Std. Deviation & 4.762 & \\
Minimum & 70 & \\
& Maximum & 84 & \\
& Range & 14 & \\
& Interquartile & 9 & .398 \\
& Range & & .039 \\
& Skewness & .1 .599 & \\
\hline
\end{tabular}




$$
\begin{aligned}
& \text { Volume : } 06 \\
& \text { Nomor }: 03 \\
& \text { Bulan }: \text { September } \\
& \text { Tahun }: 2020 \\
& \text { http }
\end{aligned}
$$

\begin{tabular}{|c|c|c|c|c|c|c|}
\hline & \multicolumn{3}{|c|}{ Kolmogorov-Smirnov ${ }^{\mathrm{a}}$} & \multicolumn{3}{|c|}{ Shapiro-Wilk } \\
\hline & Statistic & $\mathrm{df}$ & Sig. & Statistic & $\mathrm{df}$ & Sig. \\
\hline $\mathrm{X}_{1}$ & .151 & 35 & .043 & .923 & 35 & .017 \\
\hline $\mathrm{X}_{2}$ & .150 & 35 & .046 & .916 & 35 & .011 \\
\hline $\mathrm{Y}$ & .183 & 35 & .004 & .893 & 35 & .003 \\
\hline \multicolumn{7}{|c|}{ a. Lilliefors Significance Correction } \\
\hline
\end{tabular}

Untuk persyaratan analisis yang dapat dilakukan dalam penelitian ini adalah : Uji normalitas data menggunakan uji One-Sample Kolmogorov-Smirnov Test" (Liliefors) (Sugiyono 2012). Jika Sig > 0,05 maka data berdistribusi normal, jika Sig < 0,05 , maka data tidak berdistribusi normal.

Tabel .5. Tests of Normality

Berdasarkan Tabel .5. maka dapat disimpulkan data semua variabel berdistribusi normal karena Sig > 0,05.

Di samping uji normalitas disajikan pula uji homogenitas dengan hasil sebagai berikut :

\begin{tabular}{lcccc}
\hline \multicolumn{5}{c}{ Tabel .6.Test of Homogeneity of Variances } \\
\hline & Levene Statistic & df1 & df2 & Sig. \\
\hline $\mathrm{X}_{1}$ & 5.075 & 9 & 21 & .001 \\
$\mathrm{X}_{2}$ & 1.446 & 9 & 21 & .232 \\
\hline
\end{tabular}

Tabel. 6. di atas memperlihatkan bahwa terdapat signifikansi antara motivasi kerja $\left(\mathrm{X}_{1}\right)$ terhadap prestasi kerja guru $(\mathrm{Y})$ sebesar 0,001, sedangkan disiplin $\left(\mathrm{X}_{2}\right)$ terhadap prestasi kerja guru $(\mathrm{Y})$ sebesar 0,232. Karena signifikasi lebih besar dari 0,05 maka dapat disimpulkan bahwa motivasi kerja $\left(\mathrm{X}_{1}\right)$ dan disiplin $\left(\mathrm{X}_{2}\right)$ terhadap

\begin{tabular}{|c|c|c|c|c|c|c|}
\hline \multicolumn{7}{|c|}{ Coefficients $^{\mathbf{a}}$} \\
\hline \multirow[b]{2}{*}{ Model } & & \multicolumn{2}{|c|}{ Unstandardized Coefficients } & \multicolumn{3}{|c|}{ Standardized Coefficients } \\
\hline & & $\mathrm{B}$ & Std. Error & Beta & $\mathrm{t}$ & Sig. \\
\hline 1 & (Constant) & -9.346 & 14.908 & & -.627 & .535 \\
\hline & $\mathrm{X}_{1}$ & 1.159 & .201 & .709 & 5.777 & .000 \\
\hline
\end{tabular}
prestasi kerja guru $(\mathrm{Y})$ mempunyai varian yang sama.

Dengan program SPSS 17.0 for windows diperoleh nilai thitung dan signifikansinya seperti yang terdapat pada Tabel 4.7. berikut ini:

Tabel . 7.thitung dan Signifikansi Variabel Motivasi Kerja Guru IPA $\left(\mathrm{X}_{1}\right)$ terhadap Variabel Prestasi Kerja(Y)

Dengan program SPSS 17.0 for windows (Sudjana 2005) diperoleh nilai $t_{\text {hitung }}$ dan signifikansinya seperti yang terdapat pada Tabel 4.8. berikut ini: 
Tabel .8. thitung dan Signifikansi Variabel Disiplin $\left(X_{1}\right)$ terhadap variabel Prestasi Kerja Guru (Y) Coefficients $^{a}$

\begin{tabular}{|c|c|c|c|c|c|c|}
\hline \multirow[b]{2}{*}{ Model } & & \multicolumn{2}{|c|}{ Unstandardized Coefficients } & \multicolumn{3}{|c|}{ Standardized Coefficients } \\
\hline & & $B$ & Std. Error & Beta & $t$ & Sig. \\
\hline 1 & (Constant) & -10.452 & 12.537 & & -.834 & .410 \\
\hline & $X_{2}$ & 1.164 & .167 & .771 & 6.959 & .000 \\
\hline
\end{tabular}

Uji t dilakukan untuk menguji signifikansi regresi variabel motivasi kerja $\left(\mathrm{X}_{1}\right)$ disiplin $\left(\mathrm{X}_{2}\right)$ terhadap variabel prestasi kerja guru $(\mathrm{Y})$.

Dengan program SPSS 17.0 for windows diperoleh nilai thitung dan signifikansinya seperti yang terdapat pada Tabel .9 . berikut ini:

Tabel .9. thitung dan Signifikansi Variabel Motivasi Kerja $\left(X_{1}\right)$ Disiplin $\left(X_{2}\right)$ terhadap variabel Prestasi Kerja Guru (Y)

\begin{tabular}{llccccc}
\hline \multicolumn{7}{c}{ Coefficients $^{\mathrm{a}}$} \\
\hline \multirow{2}{*}{ Model } & & \multicolumn{6}{c}{ Unstandardized Coefficients } & Standardized Coefficients & \\
\cline { 2 - 7 } & & B & Std. Error & Beta & t & Sig. \\
\hline & (Constant) & -31.481 & 12.918 & & -2.437 & .021 \\
& $\mathrm{X}_{1}$ & .634 & .199 & .388 & 3.180 & .003 \\
& $\mathrm{X}_{2}$ & .816 & .184 & .541 & 4.434 & .000 \\
\hline
\end{tabular}

a. Dependent Variable: Y

Selanjutnya penghitungan normalitas untuk setiap variabel dapat diuraikan sebagai berikut. Lalu pengujian hipotesis dilakukan dengan menggunakan analisa korelasi product moment pearson dalam program SPSS for windows 17.0. Kekuatan hubungan antara motivasi kerja dengan prestasi kerja guru ditunjukkan oleh koefisien korelasi product moment $\mathrm{r}=0,490$ dengan signifikan $\mathrm{p}<0,05$. Hasil analisis dapat dilihat pada tabel berikut :

Tabel .10.Korelasi $\mathrm{X}_{1}$ terhadap $\mathrm{Y}$

\begin{tabular}{|c|c|c|c|c|}
\hline \multicolumn{5}{|c|}{ Correlations } \\
\hline \multicolumn{3}{|c|}{ Control Variables } & $\mathrm{X}_{1}$ & $\mathrm{Y}$ \\
\hline \multirow[t]{3}{*}{$\mathrm{Y}$} & $\mathrm{X}_{1}$ & Correlation & 1.000 & .490 \\
\hline & & Significance (2-tailed) & & .003 \\
\hline & & Df & 0 & 32 \\
\hline
\end{tabular}

Dengan demikian, (Sudjana 2014) maka hipotesis nihil $\left(\mathrm{H}_{0}\right)$ yang menyatakan bahwa : tidak ada hubungan antara motivasi kerja dengan prestasi kerja guru, ditolak. Sedangkan hipotesis alternatif $\left(\mathrm{H}_{1}\right)$ yang menyatakan bahwa : ada hubungan antara motivasi kerja dengan prestasi kerja guru, diterima.

Berdasarkan hasil tersebut disimpulkan bahwa koefisien korelasi antara motivasi kerja guru IPA $\left(\mathrm{X}_{1}\right)$ dengan prestasi kerja guru $(\mathrm{Y})$ sebesar 0,490 adalah signifikan. Dengan demikian terdapat hubungan yang positif antara motivasi kerja $\left(\mathrm{X}_{1}\right)$ 


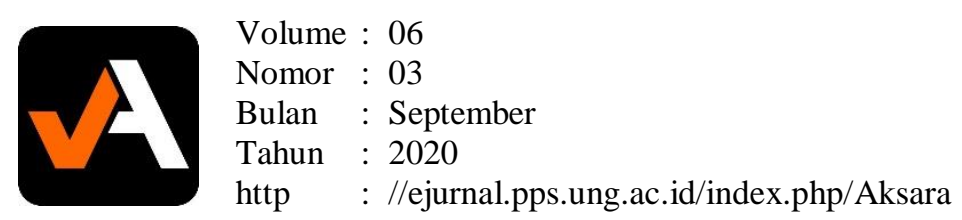

dengan prestasi kerja guru $(\mathrm{Y})$. Dengan kata lain makin baik motivasi kerja $\left(\mathrm{X}_{1}\right)$ makin baik pula prestasi kerja guru maka hipotesis dapat diterima karena teruji kebenarannya.

Selanjutnya dilakukan analisis regresi untuk melihat konstribusi $\mathrm{X}_{1}$ mempengaruhi Y, yaitu:

Dengan melakukan analisis regresi linier sederhana dengan bantuan SPSS 17.0 for windows dapat dilihat bahwa nilai koefisien korelasi $(\mathrm{R})=0,709$ yang berarti hubungan variabel motivasi kerja $\left(\mathrm{X}_{1}\right)$ terhadap variabel prestasi kerja guru $(\mathrm{Y})$ positif dan cukup kuat. Lebih jelasnya dapat dilihat pada tabel .11 sebagai berikut:

Tabel .11. Nilai Koefesien Korelasi (R) dan Koefisien Determinasi (R Square) Dari Variabel Motivasi Kerja Guru IPA $\left(\mathrm{X}_{1}\right)$ Terhadap Variabel Prestasi Kerja Guru

(Y)

\begin{tabular}{|c|c|c|c|c|}
\hline \multicolumn{5}{|c|}{ Model Summary ${ }^{b}$} \\
\hline Model & $\mathrm{R}$ & R Square & Adjusted R Square & Std. Error of the Estimate \\
\hline 1 & $.709^{\mathrm{a}}$ & .503 & .488 & 3.409 \\
\hline \multicolumn{5}{|c|}{ a. Predictors: (Constant), X1 } \\
\hline b. Depende & & & & \\
\hline
\end{tabular}

Koefisien determinasi atau R Square sebesar 0,503 adalah pengkuadratan dari koefisien korelasi. Hal ini menunjukkan 50,3\% variabel prestasi kerja guru (Y) ditentukan oleh faktor variabel motivasi kerja $\left(\mathrm{X}_{1}\right)$ sedangkan sisanya 49,7\% ditentukan faktor-faktor lain.

Berdasakan perhitungan SPSS 17.0 for windows yang terdapat pada tabel 4.7, $t_{\text {hitung }}$ variabel atas Motivasi Kerja yang diperoleh adalah sebesar 5,777 dengan df 33 pada $1 / 2 \alpha(0,05)$ dipeoleh $t_{\text {tabel }}$ sebesar 1,692 .

Dengan demikian $\mathrm{t}_{\text {hitung }}(5,777)>\mathrm{t}_{\text {tabel }}(1,692)$, sehingga jelas $\mathrm{H}_{0}$ ditolak dan $\mathrm{H}_{1}$ diterima. Hal ini menunjukan bahwa koefisien regresi variabel motivasi kerja signifikan terhadap variabel prestasi kerja guru. Dari analisis diatas dengan bantuan komputer berdasarkan perhitungan SPSS 17.0 for windows diperoleh persamaan regresi sederhana sebagai berikut: $\hat{Y}=f\left(X_{1}\right)=-9,346+1,159 X_{1}$

Konstanta sebesar $-9,346$ menyatakan bahwa jika tidak ada nilai motivasi kerja $\left(\mathrm{X}_{1}\right)$ maka prestasi kerja guru $(\mathrm{Y})$ nilainya $-9,346$, sedangkan koefisien regresi sebesar $1,159 \mathrm{X}_{1}$ menyatakan bahwa setiap penambahan 1 (satu) nilai pada variabel motivasi kerja $\left(\mathrm{X}_{1}\right)$ akan meningkatkan variabel prestasi kerja guru $(\mathrm{Y})$ sebesar 1,159 kali pada konstanta $-9,346$.

Uji $\mathrm{F}$ bertujuan untuk menguji signifikansi model regresi persepsi atas motivasi kerja $\left(\mathrm{X}_{1}\right)$ terhadap prestasi kerja guru $(\mathrm{Y})$. Hasil uji $\mathrm{F}$ seperti yang terdapat pada Tabel.12 berikut: 


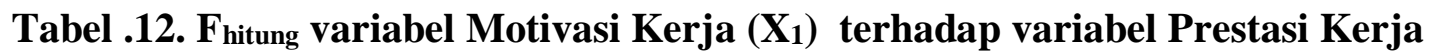
Guru (Y)

\begin{tabular}{llccccc}
\hline \multicolumn{7}{c}{ ANOVA $^{\mathbf{b}}$} \\
\hline Model & & Sum of Squares & Df & Mean Square & F & Sig. \\
\hline 1 & Regression & 387.751 & 1 & 387.751 & 33.375 & $.000^{\mathbf{a}}$ \\
& Residual & 383.392 & 33 & 11.618 & & \\
& Total & 771.143 & 34 & & & \\
\multicolumn{2}{l}{ a. Predictors: (Constant), $\mathrm{X}_{1}$} & & & & & \\
\multicolumn{2}{l}{ b. Dependent Variable: $\mathrm{Y}$} &
\end{tabular}

Dengan bantuan pengolahan komputer berdasarkan perhitungan SPSS 17.0 for windows tersebut (Sudrajat 2010) diperoleh $F_{\text {hitung sebesar 33,375 sedangkan harga kritis }}$ nilai $F_{\text {tabel }}$ dengan derajat bebas pembilang 1 dan penyebut 34 pada $1 / 2 \alpha(0,05)$ sebesar 4,130 .

Dengan demikian $\mathrm{F}_{\text {hitung }}(33,375)>\mathrm{F}_{\text {tabel }}(4,130)$, sehingga jelas $\mathrm{H}_{0}$ ditolak dan $\mathrm{H}_{1}$ diterima. Hal ini menunjukkan bahwa model regresi variabel motivasi kerja tidak signifikan terhadap variabel prestasi kerja guru.

Lalu pengujian hipotesis dilakukan dengan menggunakan analisa korelasi product moment pearson dalam program SPSS for windows 17.0. Kekuatan hubungan antara motivasi kerja dengan prestasi kerja guru ditunjukkan oleh koefisien korelasi product moment $\mathrm{r}=0,617$ dengan signifikan $\mathrm{p}<0,05$. Hasil analisis dapat dilihat pada tabel berikut :

Tabel .13. Korelasi $X_{2}$ terhadap Y

\section{Correlations}

\begin{tabular}{llcc}
\multicolumn{2}{l}{ Control Variables } & $\mathrm{X}_{2}$ & $\mathrm{Y}$ \\
\hline $\mathrm{Y} \quad \mathrm{X} 2$ & Correlation & .617 & 1.000 \\
& Significance (2-tailed) & .000 &. \\
& Df & 32 & 0 \\
\hline
\end{tabular}

Dengan demikian, maka hipotesis nihil $\left(\mathrm{H}_{0}\right)$ yang menyatakan bahwa : tidak ada hubungan antara disiplin dengan prestasi kerja guru, ditolak. Sedangkan hipotesis alternatif (H1) yang menyatakan bahwa : ada hubungan antara disiplin dengan prestasi kerja guru, diterima.

Berdasarkan hasil tersebut disimpulkan bahwa koefisien korelasi antara disiplin $\left(\mathrm{X}_{2}\right)$ dengan prestasi kerja guru $(\mathrm{Y})$ sebesar 0,617 adalah signifikan. Dengan demikian terdapat hubungan yang positif antara disiplin $\left(\mathrm{X}_{2}\right)$ dengan prestasi kerja guru $(\mathrm{Y})$. Dengan kata lain makin baik disiplin $\left(\mathrm{X}_{2}\right)$ makin baik pula prestasi kerja guru maka hipotesis dapat diterima karena teruji kebenarannya.

Selanjutnya dilakukan analisis regresi untuk melihat konstribusi $\mathrm{X}_{2}$ mempengaruhi Y, yaitu:

Dengan melakukan analisis regresi linier sederhana dengan bantuan SPSS 17.0 for windows dapat dilihat bahwa nilai koefisien korelasi $(\mathrm{R})=0,771$ yang berarti hubungan variabel disiplin $\left(\mathrm{X}_{2}\right)$ terhadap variabel prestasi kerja guru $(\mathrm{Y})$ positif dan cukup kuat. Lebih jelasnya dapat dilihat pada tabel.14 sebagai berikut: 


$$
\begin{aligned}
& \text { Volume : } 06 \\
& \text { Nomor }: 03 \\
& \text { Bulan }: \text { September } \\
& \text { Tahun }: 2020 \\
& \text { http }
\end{aligned}
$$

Tabel .14. Nilai Koefesien Korelasi (R) dan Koefisien Determinasi (R Square. Dari Variabel Disiplin ( $\left.\mathbf{X}_{2}\right)$ Terhadap Variabel Prestasi Belajar Siswa (Y)

\begin{tabular}{|c|c|c|c|c|}
\hline \multicolumn{5}{|c|}{ Model Summary ${ }^{\mathbf{b}}$} \\
\hline Model & $\mathrm{R}$ & R Square & $\begin{array}{l}\text { Adjusted R } \\
\text { Square }\end{array}$ & $\begin{array}{l}\text { Std. Error of the } \\
\text { Estimate }\end{array}$ \\
\hline 1 & $.771^{\mathrm{a}}$ & .595 & .582 & 3.077 \\
\hline \multicolumn{5}{|c|}{ a. Predictors: (Constant), X2 } \\
\hline \multicolumn{5}{|c|}{ b. Dependent Variable: Y } \\
\hline
\end{tabular}

Koefisien determinasi atau R Square sebesar 0,595 adalah pengkuadratan dari koefisien korelasi. Hal ini menunjukkan 59,5\% variabel prestasi kerja guru (Y) ditentukan oleh faktor variabel disiplin $\left(\mathrm{X}_{1}\right)$ sedangkan sisanya $40,5 \%$ ditentukan faktor-faktor lain.

Berdasarkan perhitungan SPSS 17.0 for windows yang terdapat dalam tabel 4.8, thitung variabel disiplin yang diperoleh adalah sebesar 6,959 dengan df 33 pada $1 / 2 \alpha$ $(0,05)$ dipeoleh $t_{\text {tabel }}$ sebesar 1,692.

Dengan demikian $t_{\text {hitung }}(6,959)>t_{\text {tabel }}(1,692)$, sehingga jelas $\mathrm{H}_{0}$ ditolak dan $\mathrm{H}_{1}$ diterima. Hal ini menunjukan bahwa koefisien regresi variabel disiplin signifikan terhadap variabel prestasi kerja guru. Dari analisis diatas dengan bantuan komputer berdasarkan perhitungan SPSS 17.0 for windows diperoleh persamaan regresi sederhana sebagai berikut: $\hat{\mathrm{Y}}=\mathrm{f}\left(\mathrm{X}_{1}\right)=-10,452+1,164 \mathrm{X}_{2}$

Konstanta sebesar -10,452 menyatakan bahwa jika tidak ada nilai disiplin $\left(\mathrm{X}_{2}\right)$ maka prestasi kerja guru (Y) nilainya -10,452, sedangkan koefisien regresi sebesar $1,164 \mathrm{X}_{1}$ menyatakan bahwa setiap penambahan 1 (satu) nilai pada variabel disiplin $\left(\mathrm{X}_{2}\right)$ akan meningkatkan variabel prestasi kerja guru (Y) sebesar 1,164 kali pada konstanta 10,452 .

Uji F bertujuan untuk menguji signifikansi model regresi disiplin $\left(\mathrm{X}_{2}\right)$ terhadap prestasi kerja guru (Y). Hasil uji F seperti yang terdapat pada Tabel.15 berikut:

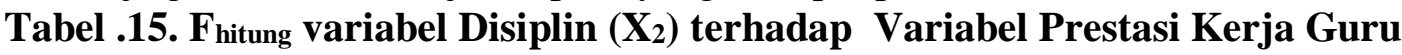
(Y)

\begin{tabular}{|c|c|c|c|c|c|c|}
\hline \multicolumn{7}{|c|}{ ANOVA $^{b}$} \\
\hline Model & & Sum of Squares & $\mathrm{df}$ & Mean Square & $\mathrm{F}$ & Sig. \\
\hline \multirow[t]{3}{*}{1} & Regression & 458.603 & 1 & 458.603 & 48.422 & $.000^{\mathrm{a}}$ \\
\hline & Residual & 312.540 & 33 & 9.471 & & \\
\hline & Total & 771.143 & 34 & & & \\
\hline
\end{tabular}

a. Predictors: (Constant), X2

b. Dependent Variable: Y

Dengan bantuan pengolahan komputer berdasarkan perhitungan SPSS 17.0 for windows tersebut diperoleh $\mathrm{F}_{\text {hitung }}$ sebesar 48,422 sedangkan harga kritis nilai $\mathrm{F}_{\text {tabel }}$ dengan derajat bebas pembilang 1 dan penyebut 34 pada $1 / 2 \alpha(0,05)$ sebesar 4,130.

Dengan demikian $\mathrm{F}_{\text {hitung }}(48,422)>\mathrm{F}_{\text {tabel }}(4,130)$, sehingga jelas $\mathrm{H}_{0}$ ditolak dan $\mathrm{H}_{1}$ diterima. Hal ini menunjukkan bahwa model regresi variabel disiplin signifikan terhadap variabel prestasi kerja guru. 
Dengan melakukan analisis regresi linier sederhana dengan bantuan SPSS 17.0 for windows dapat dilihat bahwa nilai koefisien korelasi $(\mathrm{R})=0,832$ yang berarti hubungan variabel motivasi kerja $\left(\mathrm{X}_{1}\right)$ dan disiplin $\left(\mathrm{X}_{2}\right)$ terhadap variabel prestasi kerja guru (Y) positif dan cukup kuat. Lebih jelasnya dapat dilihat pada tabel .16. sebagai berikut:

Tabel .16. Nilai Koefesien Korelasi (R) dan Koefisien Determinasi (R Square) Dari Variabel Motivasi Kerja $\left(\mathrm{X}_{1}\right)$ Disiplin $\left(\mathrm{X}_{2}\right)$ Terhadap Variabel Prestasi Kerja Guru (Y)

\begin{tabular}{lcccc}
\hline Model & $\mathrm{R}$ & R Square & $\begin{array}{c}\text { Model Summary }^{\mathbf{b}} \\
\text { Adjusted R Square }\end{array}$ & Std. Error of the Estimate \\
\hline 1 & $.832^{\mathrm{a}}$ & .692 & .673 & 2.724 \\
a. Predictors: (Constant), X2, X1 & & \\
b. Dependent Variable: $\mathrm{Y}$ & & \\
\hline
\end{tabular}

Koefisien determinasi atau R Square sebesar 0,692 adalah pengkuadratan dari koefisien korelasi. Hal ini menunjukkan 69,2 \% variabel prestasi kerja guru (Y) ditentukan oleh faktor variabel motivasi kerja $\left(\mathrm{X}_{2}\right)$ dan disiplin $\left(\mathrm{X}_{1}\right)$ sedangkan sisanya $30,8 \%$ ditentukan faktor-faktor lain.

Berdasarkan perhitungan SPSS 17.0 for windows yang terdapat dalam tabel 4.9, thitung variabel disiplin yang diperoleh adalah sebesar 3,180 dengan df 33 pada $1 / 2 \alpha$ $(0,05)$ dipeoleh $t_{\text {tabel }}$ sebesar 1,692, sehingga jelas $\mathrm{H}_{0}$ ditolak dan $\mathrm{H}_{1}$ diterima

Sedangkan thitung variabel motivasi kerja yang diperoleh adalah sebesar 4,434 dengan df 33 pada $1 / 2 \alpha(0,05)$ dipeoleh $t_{\text {tabel }}$ sebesar 1,692 , sehingga jelas $\mathrm{H}_{0}$ ditolak dan $\mathrm{H}_{1}$ diterima.

Dari analisis di atas dengan bantuan komputer berdasarkan perhitungan SPSS 17.0 for windows diperoleh persamaan regresi berganda sebagai berikut: $\hat{\mathrm{Y}}=\mathrm{f}\left(\mathrm{X}_{1}, \mathrm{X}_{2}\right)=$ $-31,481+0,634 \mathrm{X}_{1}+0,816 \mathrm{X}_{2}$

Konstanta sebesar -31,481 menyatakan bahwa jika tidak ada nilai motivasi kerja $\left(\mathrm{X}_{1}\right)$ dan disiplin $\left(\mathrm{X}_{2}\right)$ maka prestasi kerja guru $(\mathrm{Y})$ memperoleh nilai -31,481.

Sedangkan koefisien regresi sebesar $0,634 \mathrm{X}_{1}$ menyatakan bahwa setiap penambahan 1 (satu) nilai pada variabel motivasi kerja $\left(\mathrm{X}_{1}\right)$ akan meningkatkan variabel prestasi kerja guru (Y) sebesar 0,634 kali pada konstanta -31,481.

Adapun koefisien regresi sebesar $0,816 \mathrm{X}_{2}$ menyatakan bahwa setiap penambahan 1 (satu) nilai pada variabel disiplin $\left(\mathrm{X}_{2}\right)$ akan meningkatkan variabel prestasi kerja guru (Y) sebesar 0,816 kali pada konstanta -31,481.

Uji $\mathrm{F}$ bertujuan untuk menguji signifikansi model regresi persepsi atas motivasi kerja $\left(\mathrm{X}_{2}\right)$ dan disiplin $\left(\mathrm{X}_{1}\right)$ terhadap prestasi kerja guru $(\mathrm{Y})$. Hasil uji $\mathrm{F}$ seperti yang terdapat pada Tabel .17 . berikut: 


Volume : 06
Nomor $: 03$
Bulan $:$ September
Tahun $: 2020$
http $\quad:$ //ejurnal.pps.ung.ac.id/index.php/Aksara

Tabel .17. F hitung variabel Persepsi atas Motivasi Kerja $\left(\mathrm{X}_{1}\right)$ dan Disiplin $\left(\mathbf{X}_{2}\right)$ terhadap variabel Prestasi Kerja Guru (Y)

\begin{tabular}{llccccc}
\multicolumn{7}{c}{ ANOVA $^{\mathbf{b}}$} \\
\hline Model & & Sum of Squares & df & Mean Square & F & Sig. \\
\hline 1 & Regression & 533.669 & 2 & 266.835 & 35.956 & $.000^{\text {a }}$ \\
& Residual & 237.474 & 32 & 7.421 & & \\
& Total & 771.143 & 34 & & &
\end{tabular}

a. Predictors: (Constant), $\mathrm{X}_{2}, \mathrm{X}_{1}$

b. Dependent Variable: $\mathrm{Y}$

Dengan bantuan pengolahan komputer berdasarkan perhitungan SPSS 17.0 tersebut diperoleh $F_{\text {hitung }}$ sebesar 35,956 $>F_{\text {tabel }}$ 4,130, sehingga jelas Ho diterima dan Ha ditolak. Hal ini menunjukkan bahwa model regresi variabel motivasi kerja dan disiplin tidak signifikan terhadap variabel prestasi kerja guru.

\section{Pembahasan}

Merujuk pada hasil analisis antara displin dan motivasi kerja guru IPA terhadap prestasi kerja, maka selanjutnya perlu dibahas eksistensi masing-masing variabel sebagai berikut:

\section{Pengaruh Motivasi Kerja Terhadap Prestasi Kerja}

Dari hasil penelitian yang dilakukan terbukti bahwa tidak terdapat pengaruh motivasi kerja terhadap prestasi kerja guru pada Nimarwati Lagundri. Kerataan hubungan antara variabel motivasi kerja terhadap prestasi kerja guru, tercermin pada besarnya nilai koefisien korelasi (r) yang dihasilkan dari perhitungan korelasi antara variabel bebas motivasi kerja $\left(\mathrm{X}_{1}\right)$ terhadap variabel terikat prestasi kerja guru (Y) yaitu sebesar 0,709.

Koefisien determinasi atau R Square sebesar 0,503 adalah pengkuadratan dari koefisien korelasi. Hal ini menunjukkan 50,3\% variabel prestasi kerja guru (Y) ditentukan oleh faktor variabel motivasi kerja $\left(X_{1}\right)$ sedangkan sisanya 49,7\% ditentukan faktor-faktor lain.

Dari perhitungan SPSS 17.0 for windows, thitung variabel motivasi kerja yang diperoleh adalah sebesar 5,777 dengan df 33 pada $1 / 2 \alpha(0,05)$ dipeoleh $t_{\text {tabel }}$ sebesar 1,692. Dengan demikian thitung 5,777 $>t_{\text {tabel }}(1,692)$, sehingga jelas $\mathrm{H}_{0}$ ditolak dan $\mathrm{H}_{1}$ diterima. Hal ini menunjukan bahwa koefisien regresi variabel motivasi kerja guru IPA signifikan terhadap variabel prestasi kerja pada SMP Nimarwati Lagundri.

Dengan bantuan pengolahan data berdasarkan perhitungan SPSS 17.0 tersebut diperoleh $F_{\text {hitung }}$ sebesar 33,375. sedangkan harga kritis nilai $F_{\text {tabel }}$ dengan derajat bebas pembilang 1 dan penyebut 34. pada $\alpha(0,05)$ sebesar 4,130. Dengan demikian $\mathrm{F}_{\text {hitung }}(33,375)>\mathrm{F}_{\text {tabel }}(4,130)$, sehingga jelas $\mathrm{H}_{0}$ ditolak dan $\mathrm{H}_{1}$ diterima. Hal ini menunjukkan bahwa model regresi variabel motivasi kerja signifikan terhadap variabel prestasi kerja guru.

2. Pengaruh Disiplin Terhadap Prestasi Kerja Guru pada SMP Nimarwati Lagundri

Dari hasil penelitian yang dilakukan terbukti bahwa tidak terdapat pengaruh disiplin terhadap prestasi kerja guru pada SMP Nimarwati Lagundri.. Keeratan hubungan antara variabel disiplin terhadap prestasi kerja guru, tercermin pada 
besarnya nilai koefisien korelasi (r) yang dihasilkan dari perhitungan korelasi antara variabel bebas disiplin $\left(\mathrm{X}_{2}\right)$ terhadap variabel terikat prestasi kerja guru $(\mathrm{Y})$ yaitu sebesar 0,771.Koefisien determinasi atau $\mathrm{R}$ Square sebesar 0,595 adalah pengkuadratan dari koefisien korelasi. Hal ini menunjukkan 59,5\% variabel prestasi kerja guru $(\mathrm{Y})$ ditentukan oleh faktor variabel disiplin $\left(\mathrm{X}_{2}\right)$ sedangkan sisanya 40,5\% ditentukan faktor-faktor lain.

Dari perhitungan SPSS 17.0 for windows, thitung variabel disiplin yang diperoleh adalah sebesar 6,959 dengan df 33 pada $1 / 2 \alpha(0,05)$ dipeoleh $t_{\text {tabel }}$ sebesar 1,962. Dengan demikian $t_{\text {hitung }}(6,959)>t_{\text {tabel }}(1,692)$, sehingga jelas $H_{0}$ ditolak dan $\mathrm{H}_{1}$ diterima.

Hal ini menunjukan bahwa koefisien regresi variabel disiplin signifikan terhadap variabel prestasi kerja guru pada SMP Nimarwati Lagundri.

Dengan bantuan pengolahan data berdasarkan perhitungan SPSS 17.0 tersebut diperoleh $F_{\text {hitung }}$ sebesar 48,422. Sedangkan harga kritis nilai $F_{\text {tabel }}$ dengan derajat bebas pembilang 1 dan penyebut 34 . pada $\alpha(0,05)$ sebesar 4,130 .

Dengan demikian $\mathrm{F}_{\text {hitung }}(48,422)>\mathrm{F}_{\text {tabel }}(4,130)$, sehingga jelas $\mathrm{H}_{0}$ ditolak dan $\mathrm{H}_{1}$ diterima. Hal ini menunjukkan bahwa model regresi variabel disiplin signifikan terhadap variabel prestasi kerja guru.

3. Pengaruh Motivasi Kerja dan Motivasi Berprestasu Terhadap Prestasi Kerja Guru pada SMP Nimarwati Lagundri.

Dari hasil penelitian yang dilakukan terbukti bahwa tidak terdapat motivasi kerja dan disiplin terhadap prestasi kerja guru pada SMP Nimarwati Lagundri. Keeratan hubungan antara variabel disiplin terhadap prestasi kerja guru, tercermin pada besarnya nilai koefisien korelasi (r) yang dihasilkan dari perhitungan korelasi antara variabel bebas motivasi kerja $\left(\mathrm{X}_{1}\right)$ disiplin $\left(\mathrm{X}_{2}\right)$ terhadap variabel terikat prestasi kerja guru (Y) yaitu sebesar 0,832 .

Koefisien determinasi atau R Square sebesar 0,692 adalah pengkuadratan dari koefisien korelasi. Hal ini menunjukkan $69,2 \%$ variabel prestasi kerja guru (Y) ditentukan oleh faktor variabel motivasi kerja $\left(\mathrm{X}_{1}\right)$ dan disiplin $\left(\mathrm{X}_{2}\right)$ sedangkan sisanya 30,8\% ditentukan faktor-faktor lain.

Berdasarkan perhitungan SPSS 17.0 for windows, thitung variabel Motivasi Kerja dan Disiplin yang diperoleh adalah sebesar 4,434 dengan df 33 pada $1 / 2 \alpha$ $(0,05)$ dipeoleh $t_{\text {tabel }}$ sebesar 1,692. Dengan demikian $t_{\text {hitung }}(4,434)>t_{\text {tabel }}(1,692)$, sehingga jelas $\mathrm{H}_{0}$ ditolak dan $\mathrm{H}_{1}$ diterima.

Hal ini menunjukan bahwa koefisien regresi variabel motivasi kerja dan disiplin signifikan terhadap variabel prestasi kerja guru pada SMP Nimarwati Lagundri. Dengan bantuan pengolahan data berdasarkan perhitungan SPSS 17.0 tersebut diperoleh $F_{\text {hitung }}$ sebesar 35,956 Sedangkan harga kritis nilai $F_{\text {tabel }}$ dengan derajat bebas pembilang 1 dan penyebut 34. pada $\alpha(0,05)$ sebesar 4,130 .

Dengan demikian $F_{\text {hitung }}(35,956)>\mathrm{F}_{\text {tabel }}(4,130)$, sehingga jelas $\mathrm{H}_{0}$ ditolak dan $\mathrm{H}_{1}$ diterima. Hal ini menunjukkan bahwa model regresi variabel motivasi kerja dan disiplin signifikan terhadap variabel prestasi kerja guru. 


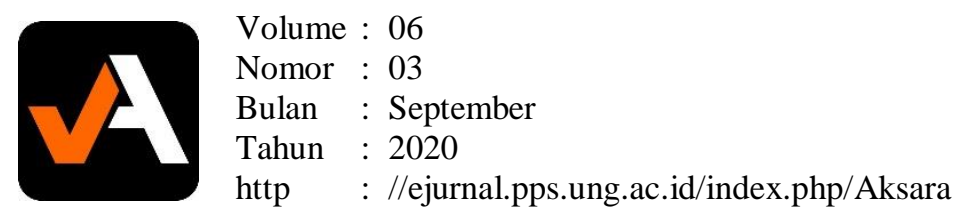

\section{SIMPULAN}

Hasil pengujian hipotesis diperoleh kesimpulan bahwa terdapat hubungan yang signifikan antara dengan motivasi kerja guru IPA dan displin, kemudian terdapat hubungan yang signifikan antara motivasi kerja dengan prestasi kerja guru. Adapun hubungan regresi bersifat linier secara bersama-sama terdapat hubungan positif yang signifikan antara variabel bebas motivasi kerja guru IPA $\left(\mathrm{X}_{1}\right)$ dan disiplin $\left(\mathrm{X}_{2}\right)$ dengan variabel terikat prestasi kerja (Y).

\section{DAFTAR PUSTAKA}

A.S. Moenir. 2010. Manajemen Pelayanan Umum Di Indonesia. Jakarta: Bumi Aksara. Anoraga, Pandji. 2012. Manajemen Bisnis. Jakarta: Rineka Cipta.

Atmodiwirjo. 2000. Manajemen Pendidikan Indonesia. Jakarta: Ardaditiya.

Bejo, Siswanto. 2005. Manajemen Tenaga Kerja Indonesia Pendekatan Administrarif Dan Operasional. Jakarta: Bumi Aksara.

Djoko Prakoso dan I ketut Murtika. 2004. Hukum Asuransi Indonesia. Jakarta: Asdi mahastya.

Fathoni. 2006. Manajemen Sumber Daya Manusia. Bandung.: Rineka Cipta.

Hagemann, Gisela. 2015. Motivasi Untuk Pembinaan Organisasi. Jakarta: PT. Pustaka.

Sanjaya, Wina. 2009. "Perencanaan Dan Desain Sistem Pembelajaran." Jakarta: PT. Prenada Media Group.

Sardiman. 2011. Interaksi Dan Motivasi Belajar-Mengajar. Jakarta: Raja Grafindo Persada.

Sudjana. 2005. Metode Statiska. Bandung: Tarsito.

Sudjana, Nana. 2014. Penelitian Hasil Proses Belajar Mengajar. Bandung.: Remaja Rosdakarya.

Sudrajat, Subana dan. 2010. "Statistik Pendidikan Refisi." Bandung: PT. Pustaka Setia.

Sugiyono. 2012. Metode Penelitian. Bandung: Alfabeta.

Supardi, U. .. 2012. Aplikasi Statistika Dalam Penelitian. Jakarta: PT. Ufuk Publishing House.

Trianto. 2009. "Mendesain Model Pembelajaran Inovatif-Progresif." Jakarta: PT. Kencana Prenada Media Grup. 